\title{
TANGGUNG JAWAB KARYAWAN DALAM PELAKSANAAN PEKERJAAN DI USAHA DAGANG FAHMI MEUBEL KECAMATAN KWANDANG KABUPATEN GORONTALO UTARA
}

\author{
Andi Yusuf Katili \& Yuliana Kaluku \\ STIA Bina Taruna Gorontalo \\ yusuf2801@gmail.com ${ }^{1}$ \& bukujurnalstia@binataruna.ac.id ${ }^{2}$
}

\begin{abstract}
ABSTRAK
Tujuan penelitian ini untuk mengetahui Tanggung Jawab Karyawan Dalam Pelaksanaan Pekerjaan Di Usaha Dagang Fahmi Meubel Kecamatan Kwandang Kabupaten Gorontalo Utara. Penelitian ini menggunakan deskrisptif kualitatif. Pengumpulan data dilakukan melalui observasi dan wawancara menggunakan pedoman wawancara yang diajukan kepada sejumlah informan. Teknik analisis data menggunakan teknik analisis data yaitu pengumpulan data, reduksi data, display data, verifikasi dan penegasan kesimpulan.

Hasil penelitian menunjukkan bahwa: 1. Masih ada karyawan yang sering terlambat dalam dalam waktu memulai pekerjaan, dimulai dari karyawan yang memiliki tugas dalam memproduksi perabotan rumah tangga, sampai karyawan yang bertugas sebagai penjual kurang menaati aturan serta kedisiplinan dalam bekerja tersebut. 2. Masih belum berjalan secara efesien dan tujuan yang diharapkan perusahaan belum bisa mencapai target sesuai pesanan para konsumen dan ada pula sebagian karyawan dalam menjalankan tugasnya masih ada yang terbengkalai, hal ini bisa menimbulkan keterlambatan penyelesain produk yang telah dipesan oleh konsumen. 3. Semangat kerja karyawan yang ada di Usaha Dagang (UD) Fahmi Meubel masih kurang, ada juga terdapat hasil produksi perabotan lainnya yang tidak sesuai dengan target pesanan atau jangka waktu yang telah ditentukan. 4 Kreatif kerja yang dilakukan karyawan yang ada di Usaha Dagang (UD) Fahmi Meubel belum sepenuhnya berjalan sesuai yang diharapkan, masih perlu pembenahan oleh pihak perusahaan

Disarankan: 1 Diharapkan disiplin yang dimiliki oleh seorang karyawan yang ada di Usaha Dagang (UD) Fahmi Meubel bisa menjadi suatu perhatian bagi setiap karyawan, agar diwaktu pelaksnaan pekerjaan tidak ada yang terlambat dan mentaati aturan yang ada. 2 Diharapkan Kerja sama yang dilakukan oleh karyawan bisa berjalan dengan baik antara karyawan yang satu dengan yang lainnya agar produk yang dibuat bisa selesai tepat waktu sesuai target yang telah ditentukan. 3Diharapkan semangat kerja yang ada pada karyawan bisa ditingkatkan untuk tercapainya kinerja yang baik. 4 Diharapkan Kreatif kerja yang dimiliki karyawan bisa berjalan sepenuhnya, dan bisa berkereatifitas untuk memproduksi perabotan rumah tangga yang hasil jualnya cukup tinggi, dan bisa bersaing.

Kata Kunci: Tanggung Jawab, Karyawan, Pelaksanaan, Pekerjaan
\end{abstract}

PENDAHULUAN

Organisasi adalah suatu pola hubungan-hubungan yang melalui orang-orang di bawah pengarahan 
manajer untuk mengejar suatu tujuan bersama. Setiap organisasi atau perusahaan tentu ingin mencapai tujuan. Untuk mencapai tujuan tersebut, peranan manusia yang terlibat didalamnya sangat penting. Untuk menggerakkan manusia agar sesuai dengan yang dikehendaki organisasi, maka haruslah dipahami motivasi manusia yang bekerja didalam suatu organisasi tersebut, karena motivasi inilah yang menentukan perilaku orang-orang untuk bekerja, atau dengan kata lain, perilaku merupakan cerminan yang paling sederhana dari motivasi.motivasi seringkali diartikan pula sebagai faktor pendorong perilaku seseorang. Setiap aktivitas yang dilakukan oleh seseorang pasti memiliki sesuatu faktor yang mendorong aktivitas tersebut. Oleh karena itu, faktor pendorong dari seseorang untuk melakukan suatu aktivitas tertentu pada umumnya adalah kebutuhan serta keinginan orang tersebut.

Suatu kegiatan yang dinyatakan dalam bentuk usaha yang keras atau lemah. Pegawai yang memiliki pelayanan lemah atau menurun akan berdampak pula pada kinerja mereka sehingga akan berakibat pada titik maksimalnya mereka dalam menjalankan tugas dan tanggung jawabnya. Dalam melakukan sesuatu atau bekerja, setiap orang memerlukan suatu pendorong atau pelayanan. Dengan adanya motivasi, maka setiap orang akan lebih bersemangat dan lebih giat untuk mencapai tujuan yang diinginkan. Pelayanan merupakan bagian dari perilaku organisasi yang menyangkut dorongan yang memberikan semangat kerja kepada para pegawai untuk mencapai tujuan dalam suatu organisasi yang telah ditetapkan.

Pelayanan erat kaitannya dalam upaya peningkatan kinerja karyawan yang dalam hal ini dipengaruhi oleh beberapa faktor, baik yang berasal dari dalam diri pribadi karyawan itu sendiri maupun dari faktor lingkungan yang mempunyai kaitan dalam meningkatkan produktivitas kerja karyawan. Untuk dapat memiliki kinerja yang diharapkan, seorang pegawai dalam melaksanakan pekerjaannya harus senantiasa memiliki motivasi dalam bekerja. Kinerja pegawai dalam bidang pekerjaan apapun sangat dipengaruhi oleh besarnya motivasi dari pegawai tersebut, karena motivasi setiap orang atau pegawai berbeda-beda. Namun pelayanan dapat ditingkatkan, salah satunya adalah memenuhi kebutuhan dari pegawai tersebut diharapkan akan meningkatkan kinerja kerja para pegawai tersebut secara umum.

Manusia atau pekerja pada umumnya akan bersemangat dan bergairah kerja serta mempunyai pelayanan kerja yang baik, apabila aspek-aspek dalam pekerjanya seperti pengalaman kerja, pendidikan dan latihan, upah kerja, serta pemberian insentif tersebut sesuai dengan harapan pekerja. Sangat penting disadari oleh setiap pimpinan dalam suatu organisasi, adanya teknik-teknik untuk dapat memelihara prestasi dan kepuasan kerja karyawan, antara lain adalah memberikan pelayananatau melaksanakan tugas mereka sesuai dengan aturan dan pengarahan. 


\begin{abstract}
Faktor-faktor yang memungkinkan untuk digunakan oleh perusahaan dalam meningkatkan pelayanan kerjanya guna meningkatkan produktifitas kerja karyawan, di antaranya gaji yang sesuai dengan indeks kehidupan lokal, training bagi karyawan-karyawan tertentu yang memiliki prospek yang bagus di masa depan, pelayanan individual maupun kolektif melalui berbagai cara misalnya pemberian insentif yang proporsional dengan motivasi kerjanya, atau promosi jabatan yang diharapkan dapat mengubah tingkat kehidupannya sehingga menjadi lebih baik.
\end{abstract}

Perusahaan tanpa karyawan ibarat manusia tanpa darah. Hal itu menggambarkan betapa pentingnya karyawan dalam sebuah perusahaan walaupun banyak pemilik perusahaan yang tidak menyadari tentang hal itu. Tidak sedikit pemilik sebuah perusahaan yang memperlakukan karyawannya dengan tidak manusiawi sehingga berakibat fatal terhadap kelangsungan perusahaan itu sendiri dalam jangka panjang. Yang paling ideal adalah memperlakukan karyawan seperti layaknya seorang partner yang saling membutuhkan. Sehingga penting bagi seorang owner untuk memperhatikan hal paling detail sekalipun dari seorang karyawan. Seperti halnya tingkat pendapatan yang layak, jaminan kesehatan serta hari tua yang memadai, dll. Disadari atau tidak, secara langsung atau tidak langsung, hal-hal tersebut akan sangat berpengaruh terhadap kualitas kerja serta loyalitas karyawan terhadap perusahaan.
Pelayanan kerja dari seorang pimpinan kepada karyawan adalah suatu pendorong semangat kerja kepada karyawan dengan berbagai macam cara yang dibuat oleh seorang pimpinan kepada karyawannya, manfaat dari motivasi kerja juga untuk menumbuhkan semangat atau keinginan karyawan untuk bisa bertanggung jawab sepenuhnya terhadap kinerja, hal itu bisa saja meningkatkan tingkat kepuasan dan pendapatan suatu instansi atau perusahaan.

Dalam suatu organisasi atau perusahaan, motivasi kerja pegawai masih kurang didayagunakan secara optimal dalam rangka mencapai tujuan organisasi atau perusahaan, oleh karena itu pimpinan harus dapat memperhatikan semangat dan kegairahan kerja para pegawainya. oleh karena itu faktor-faktor yang mempengaruhi pelayanan kerja pegawai atau hasil kerja pegawai mendapat perhatian dari suatu instansi atau organisasi dan selalu dipantau melalui penilaian kinerja pegawai. Terkait dengan prestasi kerja pegawai tidak terlepas dari pelayanan pegawai itu sendiri karena jika pegawai bekerja hanya karena terpaksa dan tidak ada motivasi maka pekerjaan yang dilakukannya tidak akan berhasil dengan baik dan maksimal. Hal ini disebabkan karena hasil yang baik didapat dari pekerjaan yang dijiwai dan didorong oleh rasa senang, serta adanya gairah dan dedikasi kerja pegawai itu sendiri, karena motivasi merupakan faktor yang mendorong pegawai untuk bersedia berbuat atau bertindak dengan cara-cara tertentu.

Faktor-faktor internal maupun eksternal yang muncul dikarenakan 
adanya suatu kebutuhan dan keinginan yang ada dalam setiap individu atau kelompok. Faktor ini mempunyai kekuatan yang mempengaruhi pikiran seseorang yang selanjutnya akan memberikan arahan pada seseorang tersebut mengenai apa yang mestinya dilakukan. Karenanya faktor internal ini yang akan banyak memberikan arahan pada diri setiap individu sehingga baik buruknya hasil pekerjaan yang dikerjakan sangat tergantung dari kekuatan pengaruh faktor internal. Selain itu yang ikut memberikan warna pada arah kegiatan seseorang dalam menjalankan aktifitasnya adalah faktor eksternal. Faktor eksternal didapat dari lingkungan dimana individu melakukan aktifitasnya seperti sikap atasan, suasana kerja, kondisi kerja, gaji, hubungan kerja, penghargaan, kenaikan pangkat dan rasa tanggung jawab atas pekerjaan yang dibebankan kepada masingmasing individu.

$$
\text { Usaha Dagang (UD) di }
$$

Kecamatan Kwandang Kabupaten Gorontalo Utara yang bergerak di bidang perabotan rumah tangga dengan nama Fahmi Meubel. Usaha tersebut berjalan sejak tahun 2012 dengan jumlah karyawan sebanyak 20 orang. Adapun perkembangan UD Fahmi Meubel pada 2 tahun belakangan ini mengalami penurunan hasil pendapatan, yang disebabkan oleh kurangnya rasa tanggung jawab karyawan terhadap pekerjaannya. Contohnya ketika pemilik usaha tersebut tidak berada di tempat kerja maka para karyawan seenaknya dalam memproduksi dan melayani pembeli sehingga minat masyarakat untuk membeli barang kebutuhan perabotan rumah tangga berkurang.

Tingkat kedisiplinan dari karyawan juga sangat menentukan tingkat kemajuan perusahaan tersebut, namun selama ini tingkat kedisiplinan tersebut yang tidak ada, contohnya dalam hal waktu, karyawan sering terlambat memulai terutama karyawan yang memiliki tugas dalam memproduksi perabotan rumah tangga, sampai dengan karyawan yang bertugas sebagai penjual, kurang menaati aturan serta kedisiplinan dalam kerja tersebut. Dalam suatu pekerjaan yang dilakukan dalam UD Fahmi Meubel sering tidak terselesaikan sesuai waktu yang ditentukan, contoh pembuatan kursi sofa sesuai dengan pesanan konsumen yang sering tertunda, hal itu juga dikarenakan oleh kurangnya kerja sama karyawan dalam menyelesaikan pekerjaan yang telah ditentukan.

Semangat kerja sangat diperlukan dalam melaksanakan tanggung jawab karyawan di UD Fahmi Meubel Kecamatan Kwandang namun semangat kerja karyawan tersebut sesuai dengan observasi awal peneliti masih kurang. Hal itu nampak dengan adanya masalah hasil produksi kursi dan perabotan lainnya yang tidak sesuai dengan target pesanan atau jangka waktu yang telah ditentukan. Ada beberapa hal yang mengakibatkan kurangnya semangat kerja karyawan dalam melakukan pekerjaan. Contohnya upah gaji karyawan tidak sesuai dengan apa yang diharapkan oleh karyawan dimana pembayaran gaji tidak tepat pada waktunya dan pemimpin tersebut menekan kepada karyawan 
meubel untuk mencapai target pembuatan kursi sofa untuk konsumen, dan pemimpin juga tidak memiliki hubungan emosional terhadap karyawan yang ada di UD Fahmi Meubel Kecamatan Kwandang.

Masalah berikutnya adalah masalah yang muncul diakibatkan oleh hasil produk atau hasil pekerjaan yang kurang memuaskan keinginan konsumen, contohnya corak ukiran kayu pada kursi yang kurang rapi pekerjaannya, hal itu diakibatkan oleh kurangnya kreatifitas kerja karyawan dalam melakukan pekerjaan sehingga tingkat kepuasan dari konsumen tidak terwujud.

\section{PERMASALAHAN}

Berdasarkan uraian tersebut di atas, maka rumusan, masalah dalam penelitian adalah bagaimana Tanggung Jawab Karyawan Dalam Pelaksanaan Pekerjaan di Usaha Dagang (UD) Fahmi Meubel di Kecamatan Kwandang Kabupaten Gorontalo Utara?

\section{TUJUAN DAN MANFAAT PENELITIAN}

\section{Tujuan Penelitian}

Tujuan penelitian ini adalah untuk mengetahui Tanggung jawab karyawan dalam pelaksanaan pekerjaan di Usaha Dagang (UD) Fahmi Meubel di Kecamatan Kwandang Kabupaten Gorontalo Utara.

\section{Manfaat Penelitian}

Adapun manfaat penelitian dicapai diharapkan memperoleh manfaat baik secara teoritis maupun manfaat praktis, di antaranya:

Secara teoritis penelitian ini bermanfaat dalam pengembangan ilmu pengetahuan khususnya ilmu administrasi serta dapat dijadikan sebagai bahan referensi bagi penelitian yang sejenis yaiut bahwa suatu usaha dagang berkembang apabila ada motivasi kerja karyawan itu sendiri.

Secara praktis penelitian ini diharapkan kiranya dapat dijadikan sebagai bahan informasi alternatif bagi pemecahan masalah yang berkaitan dengan Tanggung jawab karyawan dalam pelaksanaan pekerjaan di Usaha Dagang (UD) Fahmi Meubel di Kecamatan Kwandang Kabupaten Gorontalo Utara dalam Mendukung pelaksanaan pengembangan usaha dagang (UD) itu sendiri.

\section{METODE PENELITIAN}

Jenis penelitian mengenai Tanggung jawab karyawan dalam pelaksanaan pekerjaan di Usaha Dagang (UD) Fahmi Meubel di Kecamatan Kwandang Kabupaten Gorontalo Utara) Fahmi Meubel Di Kecamatan Kwandang Kabupaten Gorontalo Utara adalah jenis penelitian deskriptif dengan menggunakan pendekatan kualitatif. Menurut Sugiyono (2010:15), menjelaskan bahwa: Metode penelitian kualitatif merupakan metode penelitian yang berlandaskan pada filsafat positivisme, digunakan untuk meneliti pada kondisi obyek yang alamiah, (sebagai lawannya adalah eksperimen) dimana peneliti adalah sebagai instrumen kunci, 
pengambilan sampel sumber data dilakukan secara purposive dan snowball, teknik pengumpulan dengan trianggulasi, analisis data bersifat induktif/kualitatif, dan hasil penelitian kualitatif lebih menekan makna dari pada generalisasi.

Menurut

Sukmadinata (2009:53-60) penelitian kualitatif adalah penelitian yang digunakan untuk mendeskripsikan dan menganalisis fenomena, peristiwa, aktivitas sosial, sikap, kepercayaan, presepsi, dan orang secara individual maupun kelompok. Sukmadinata (2009:18), menyatakan bahwa penelitian deskriptif bertujuan mendefinisikan suatu keadaan atau fenomena secara apa adanya. Berdasarkan uraian di atas dapat disimpulkan bahwa jenis penelitian ini menggunakan penelitian kualitatif karena analisis datanya berupa katakata tertulis atau lisan dan mempertimbangkan pendapat orang lain yang bisa disebut dengan narasumber.

\section{Fokus Penelitian}

Penelitian ini difokuskan pada Tanggung jawab karyawan dalam pelaksanaan pekerjaan di Usaha Dagang (UD) Fahmi Meubel di Kecamatan Kwandang Kabupaten Gorontalo Utara sebagai berikut:

\section{Disiplin}

Disiplin yang dimaksudkan dalam penelitian ini adalah disiplin karyawan dalam melaksanakan tugas sehari-hari.

\section{Kerja sama}

Kerja sama yang dimaksudkan dalam penelitian ini adalah Kerja sama karyawan dalam melaksanakan pekerjaan.

\section{Semangat Kerja}

Semangat Kerja yang dimaksudkan dalam penelitian ini adalah komunikasi karyawan dengan pimpinan UD Fahmi Meubel.

\section{Kreatifitas Kerja}

Kreatifitas Kerja yang dimaksudkan dalam penelitian ini adalah karyawan harus kreatif dalam melakukan pekerjaan.

\section{HASIL PENELITIAN DAN PEMBAHASAN}

Hasil penelitian tentang Tanggung Jawab Karyawan Dalam Pelaksanaan Pekerjaan di Usaha Dagang (UD) Fahmi Meubel Kecamatan Kwandang Kabupaten Gorontalo Utara adalah:

Tanggung Jawab Karyawan Dalam Pelaksanaan Pekerjaan di Usaha Dagang (UD) Fahmi Meubel dilihat dari Disiplin masih ada karyawan yang sering terlambat dalam waktu memulai pekerjaan, dimulai dari karyawan yang memiliki tugas dalam memproduksi perabotan rumah tangga, sampai karyawan yang bertugas sebagai penjual kurang menaati aturan serta kedisiplinan dalam bekerja tersebut.

Tanggung Jawab Karyawan Dalam Pelaksanaan Pekerjaan di Usaha Dagang (UD) Fahmi Meubel dilihat dari Kerjasama masih belum berjalan secara efesien dan tujuan yang diharapkan perusahaan belum bias mencapai target sesuai pesanan para konsumen dan ada pula sebagian karyawan dalam menjalankan tugasnya masih ada yang 
terbengkalai, hal ini dapat menimbulkan keterlambatan penyelesain produk yang telah dipesan oleh konsumen.

Tanggung Jawab Karyawan Dalam Pelaksanaan Pekerjaan di Usaha Dagang (UD) Fahmi Meubel dilihat dari semangat kerja. Sesuai dengan observasi peneliti, semangat kerja karyawan yang ada di Usaha Dagang (UD) Fahmi Meubel masih kurang, ada juga terdapat hasil produksi perabotan lainnya yang tidak sesuai dengan target pesanan atau jangka waktu yang telah ditentukan.

Tanggung Jawab Karyawan Dalam Pelaksanaan Pekerjaan di Usaha Dagang (UD) Fahmi Meubel dilihat dari Kreatif Kerja. Kreatif kerja yang dilakukan karyawan yang ada di Usaha Dagang (UD) Fahmi Meubel belum sepenuhnya berjalan sesuai yang diharapkan, masih perlu pembenahan oleh pihak perusahaan.

\section{SIMPULAN}

Berdasarkan hasil penelitian. Maka dapat disimpulkan, bahwa:

Pemilik Usaha Dagang (UD) Fahmi Meubel belum maksimal memperhatikan kedisiplinan karyawan waktu masuk kerja dimana sering karyawan terlambat masuk kerja.

Kerjasama yang dilakukan oleh karyawan belum berjalan dengan baik antara karyawan yang satu dengan yang lainnya karena produk yang dibuat sering tidak selesai tepat waktu sesuai target yang telah ditentukan.

Semangat kerja karyawan mengalami ketidakstabilan hal ini dapat dilihat tingkat kerja belum tercapainya kinerja yang baik.

Kreatif kerja yang dimiliki karyawan belum berjalan sepenuhnya, yang menyebabkan kreatifitas untuk memproduksi perabotan rumah tangga masih rendah dan tidak cukup untuk bersaing.

\section{SARAN}

Berdasarkan kesimpulan yang telah dipaparkan di atas, maka dapat disaran sebagai berikut:

Diharapkan pemilik Usaha Dagang (UD) Fahmi Meubel memperhatikan kedisiplinan karyawan dalam jam masuk kerja agar karyawan tidak ada yang terlambat masuk kerja.

Diharapkan Kerjasama yang dilakukan oleh karyawan dapat berjalan dengan baik antara karyawan yang satu dengan yang lainnya agar produk yang dibuat bisa selesai tepat waktu sesuai target yang telah ditentukan.

Diharapkan semangat kerja yang ada pada karyawan dapat ditingkatkan untuk tercapainya kinerja yang baik.

Diharapkan Kreatif kerja yang dimiliki karyawan bisa berjalan sepenuhnya, dan dapat berkreatifitas untuk memproduksi perabotan rumah tangga yang hasil jualnya cukup tinggi, dan dapat bersaing.

\section{DAFTAR PUSTAKA}

Anggara, Sahya. 2012. Ilmu Administrasi Negar. Bandung: Pustaka Setia. 
Arikunto, S. 2013. Prosedur Penelitian: Suatu Pendekatan Praktik. Jakarta: Rineka Cipta.

A. Kurniawan. 2007. Pengukuran Tingkat Kepuasan Pelanggan. Cetakan Ketiga. Jakarta: Rineka Cipta.

Anwar. 2007. Manajemen Sumber Daya Manusia Perusahaan Barata Manajemen Pemasaran Jasa. Edisi Pertama. Jakarta: Salemba Empat

Fahmi. 2010. Manajemen Kinerja, Falsafah, Teori dan Penerapannya. Yogyakarta: Pustaka Pelajar.

Gibson. 2010. Organisasi, Perilaku, Struktur, dan Proses. Jakarta: Binapura Aksara Publisher.

Hasibuan, Malayu SP. 2005. Kemampuan Manajemen Sumber Daya Manusia. Edisi Revisi. Jakarta: Bumi Aksara.

Keban, Jeremias. 2008. Enam Dimensi Strategis Administrasi Publik: Konsep, Teori dan Isu. Yogyakarta: Penerbit Gava Media.

Mangkunegara. 2007. Motivasi dan Kepribadian. Jakarta: PT. Gramedia

Mangkunegara. 2007. Manajemen Sumber Daya Manusia Perusahaan. Cetakan keenam. Bandung: Remaja Rosda Karya.

Moh. As'ad. 2009. Perilaku Organisasi. Edisi 4. Yogyakarta: Liberty.

Moeheriono. 2009. Pengukuran Kinerja Berbasis Kompetensi. Bogor: Ghalia Indonesia.

Mangkunegara, Anwar Prabu. 2012. Manajemen Sumber Daya Manusia. Cetakan Kesembilan.
Bandung: PT. Remaja Rosdakarya.

Mangkunegara (2009) Manajemen Sumber Daya Manusia. Bandung: PT. Remaja Rosdakaya.

Patton. 2009. Metode Penelitian. Jakarta: PT. Pustaka Delapratasa.

Pasolong, Harbani. 2011. Teori Administrasi Publik. Bandung: Alfabeta.

Pasolong, Harbani. 2010. Teori Administrasi Publik. Bandung: Alfabeta

Pasolong, Harbani. 2007. Teori Administrasi Publik. Bandung: Alfabeta.

Pasolong, Harbani. 2010. Manajemen Pelayanan. Yogyakarta: Pustaka Pelajar:

Pasolong, Harbani. 2011. Teori Administrasi Publik. Bandung: Alfabeta.

Sukmadinata, N.S. 2009. Metode penelitian pendidikan. Bandung: PT Remaja Rosdakarya

Siagian. 2008. Perubahan dan Pengembangan Organisasi. Bandung: Penerbit Sinar Baru.

Suryana. 2007. Usaha Kecil Menengah dan Pembangunan. Jakarta: Ghalia Indonesia.

Suprayogi. 2011. Administrasi Publik Konsep dan Perkembangan Ilmu di Indonesia. Yogyakarta: Graha Ilmu.

Silalahi, Ulber. 2007. Metode Penelitian Sosial. Bandung: UNPAR Press

Sugiono. 2010. Metode Penelitian Kualitatif Kuantitatif \& RND Bandung: Alfabeta. 
Syafiie, Inu Kencana. 2006. Sistem

Administrasi publik Republik

Indonesia (SANKRI). Jakarta:

PT Bumi Aksara.

Siagian, P. Sondang. 2008. Administrasi Pembangunan,

Konsep, Dimensi dan

Strateginya. Jakarta: Bumi

Aksara.

Ibrahim, Amin. 2007. Teori dan

Konsep Pelayanan Publik

Serta Implementasinya.

Bandung: CV Mandar Maju.

Veithzal. 2009. Kinerja, Teori dan

Penelitian. Yogyakarta:

Liberty.

Wibowo. 2011. Budaya Organisasi:

Sebuah Kebutuhan Untuk

Meningkatkan Kinerja Jangka

Panjang. Jakarta: Rajawali

Pers.

Rivai, Veithzal. 2004. Management

Sumber Daya Manusia untuk

Perusahaan. Jakarta: Radja

Grapindo Persada

Widagdho, Djoko. 2008. Tanggung

Jawab Ilmu Budaya Dasar.

Jakarta: PT. Bumi Aksara. 